are scientists used to explaining their research to a general audience. As a result, much of China's population is insufficiently informed about science and technology issues. "It's an important aspect of building a more democratic society," says Zhu. "It will come with time."

Yet people in China are eager to obtain more information and voice their views. In Shanghai, at one of several 'café scientifique' events organized by the British Council, stem-cell researcher
Stephen Minger of King's College London and his Chinese colleagues had lively exchanges about stem-cell therapies with audiences of all ages and professions. Last month, the Beijingbased National Art Museum of China mounted an exhibition called Synthetic Times. Prominent installation artists from 29 countries explored issues such as identity, emotion, perception of reality, and the relationship between humans and technology in time and space.
"There is a lot of interest in science and technology from all sectors of the Chinese public," says Liu. "To channel that energy and curiosity properly is key to promoting the awareness of science and its social impact."

Jane Qiu is a science writer based in London and Beijing.

e-mail: jane@janeqiu.com

See Editorial, page 367.

\title{
A shared view of the heavens
}

\section{A woodcut of Ferdinand Verbiest, the Kangxi Emperor's Flemish astronomer and mastermind of Beijing's Ancient Observatory, records a remarkable seventeenth-century cultural exchange. Martin Kemp explains.}

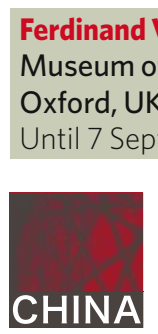

Ferdinand Verbiest: Heaven on Earth
Museum of the History of Science
Oxford, UK
Until 7 September

Not far from Beijing station, in a cityscape dominated by new buildings and multi-lane highways, stands a squat, ancient tower. On top sits the world's greatest historical ensemble of large-scale astronomical instruments. They were mainly designed and installed in 1673 by Ferdinand Verbiest, the Flemish Jesuit who was mathematician and astronomer to the Kangxi Emperor.

Verbiest makes a striking appearance in a coloured 1827 woodcut (pictured) by the Japanese artist, Utagawa Kuniyoshi. He stands in Chinese state robes, accompanied by smaller variants of his celestial globe and sextant while enumerating points on his fingers. The inscription on the print tells us that it portrays Chitasei Goyo, one of the 108 rogue heroes of the popular classical Chinese novel, Water Margin. How was the master of Chinese astronomy transformed into the clever strategist of a military gang?

The story begins with one of the most remarkable cultural exchanges of any era. It involves three successive Jesuit astronomers, sent as missionaries from Rome to China. Verbiest followed Matteo Ricci and Adam Schall von Bell to work as an astronomer at the emperor's court. The Jesuits were in fierce competition with traditional Chinese and Muslim astronomers for scientific and religious supremacy. At one stage, when the intellectual and political climate had moved against them, Schall and Verbiest were imprisoned under sentence of death by dismemberment, a gruesome fate they only narrowly avoided.

By 1699, Verbiest's star was in the ascendant with the emperor. He triumphed over his

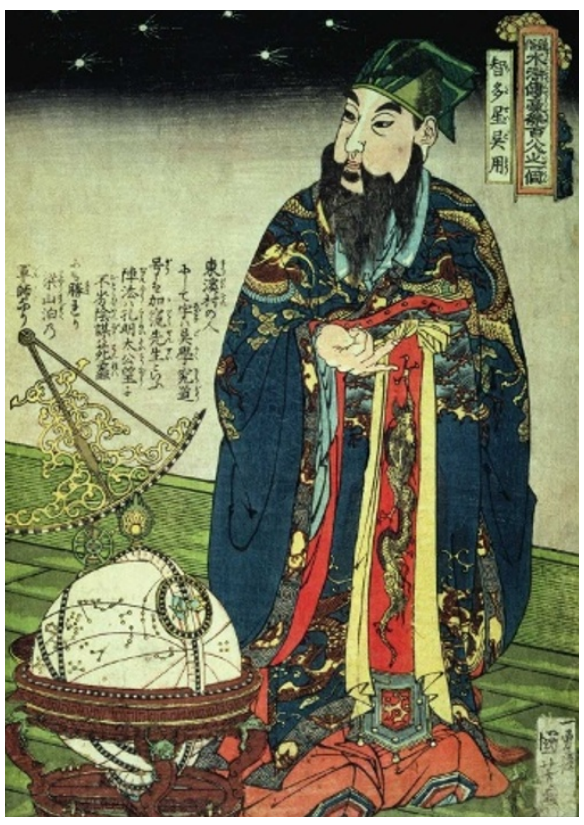

Chinese rival in a contest to demonstrate the accuracy of his science, and reformed the Chinese calendar. A notable polymath and author, who designed cannon and steam-driven vehicles among other ingenious devices, Verbiest's most enduring achievement was the set of six new instruments for Beijing's observatory tower.

Taking inspiration from Tycho Brahe's ensemble of massive astronomy instruments on the Danish island of Hven, Verbiest spared no expense in establishing the world's definitive observatory. The great bronze celestial globe, for example, is almost 2 metres in diameter, and he boasted that it cost the massive sum of 50,000 taels, or silver pieces. Then, as now, astronomy was a costly science requiring big instruments.

To bring his achievements before the widest international audience, Verbiest published a set of 105 prints, mainly devoted to his observatory instruments and their manufacture, but also demonstrating Euclidian geometry, ballistics and various notable feats of engineering. The graphic technique of his illustrations exploits western-style draftsmanship for the instruments themselves, whereas the spaces within which they are located are drawn in the Chinese manner. Thus, the celestial globe is rendered in a convincingly plastic form, but the chequerboard tiling beneath it clearly does not observe the rules of linear perspective.

The intellectual traffic between China and Europe went both ways. The presence of the Jesuit scientists at the Chinese court led to a greater awareness in Europe of the richness of Chinese history, culture, science and technology. The thoughts of Confucius were made available to western philosophers when the first Latin edition of Confucius, Philosopher of the Chinese was published in Paris in 1686, prefaced by introductions to Chinese history, theology and the philosopher's own life.

The reach of Verbiest's fame, and of his splendid instruments, was considerable, as evinced by Kuniyoshi's spectacular print. And so to the question of why the artist cast a Japanese bandit hero in the guise of the famous astronomer. The answer probably lies in Goyo's Chinese name, Wu Yong, which means 'wise star'. Verbiest's instruments thus refer in a double sense to the hero's name and to his famed wisdom as a military strategist, which required expertise in maps, navigation and the various technologies over which Verbiest claimed mastery.

These interchanges between Jesuit and Chinese science and Japanese mythology remind us that global communication thrived long before our technological era.

Martin Kemp is research professor in the history of art at the University of Oxford, OX11PT, UK.

See Editorial, page 367. 